\title{
Upaya Peningkatan Mutu Pendidikan Sekolah
}

\author{
Atno Firnando \\ E-mail: atnofirnando@gmail.com \\ Program Studi Pendidikan Bahasa dan Sastra Indonesia \\ Fakultas Keguruan dan Ilmu Pendidikan \\ Universitas Riau
}

\section{Pengantar}

Dalam kehidupan kita sebagai manusia, hari demi hari usia kita semakin bertambah dan seiring bertambahnya usia kita, maka semakin banyak pula pengalaman yang akan kita alami. Maka sebagai manusia yang berakal sehat sewajarnya kita harus merenung apakah hari ini lebih baik dari hari kemaren? Apakah hari ini masih sama dengan hari kemaren? Atau bahkan hari ini lebih buruk dari hari kemaren? Maka dari itu menusia selalu saja akan waktu berupaya meningkatkan kualiatas hidupnya waktu demi waktu. Hal ini juga di anjurkan dalam ebuah riwayat hadist yang bunyinya "barang siapa yang harinyasekarang lebih baik daripada kemarin, maka dia termasuk orang yang beruntung.

Barang siapa yang harinya sama dengan kemarin, maka dia adalah orang yang merugi. Barang siapa uang harinya sekarang lebih jelek daripada harinya lermarin, maka dia celaka" riwayat hadist ini begitu logis untuk diterima akal sehat, menjunjung tingggi akan pentingnya meningkatkan kualitas atau mutu dalam kehidupan manusia. Sekarang kehidupan manuisa semakin hari semakin banyak melewati berbagai pengalaman hidup yang ditranfer menjadi sebuah ilmu, hingga kini adanya sebuah pendidkan di sekolah untuk menunjang kualiatas kehidupan manusia, semua negara di penjuru dunia, terkhusus di negara Republik Indonesia kian hari dan kian melewati zaman, maka berbagai upaya pun dilakukan untuk selalu menigakatkan kualiatas atau mutu pendidikan. 


\section{Mutu Pendidikan Sekolah}

Mencerdaskan kehidupan bangsa, merupakan hal yang paling penting dalam perkembangan dan kemajuan suatu negara, sebagaimana terdapat dalam Undangundang Dasar 1945 Republik Indonesia, maka semua elemen rakayat Indonesia sangatlah berperan penting dalam mempengaruhi perkembangan dan kemajuan sebuah negara. Sehingga dengan adanya sekolah ini menjadi wadah utama yang berfungsi sebagai penentuny, hal ini lah yang menjadi pokok perhatian bagi seluruh masyarakat dan pemerintah sehingga perlu adanya upaya untuk selalu meningkatkat mutu di seluruh lembaga pendidikan khususnya sekolah.

Pendidikan merupakan faktor utama dalam pembentukan pribadi manusia (Hermanto 2012). Sepatutunya sebagai warga negara dalam sebuah lingkupan pemerintah kita harus eksis untu terjun langasung dalam menjamin keselamatan, kemajuan pendidkan itu sendiri. Mutu pendidikan adalah kualiatas produk yang dihasilkan lembaga pendidikan atau sekolah (Aziz, 2015; Suti, 2011). Mutu penddikan adalah kemampuan sekolah dalam pengolahan sekolah secara operasional dan efisien (Sastrawan, 2016). Dewasa ini, kian hari dan kian berganti zaman, semakin besar pula tuntutan akan mutu pendidikan untuk memenuhi kebutuhan setiap generasi. Mutu pendidikan sekolah sudah sangat menggelitik dunia pendidikan.

Pendidikan yang bermutu adalah pendidikan yang berhasil mencetak generasi berpola pokir yang berkembang dan maju serta memiliki nilai akhlak mulia dengan menerapakan sendiri sebagai contoh serta mencipatakan pemeblajaran yang aktif, kreatif, dan menyenangkan. Sejalan dengan sebuah pendapat menyatakan bahawa pendidikan yang bermutu adalah pendidikan yang mampu memenuhi harapan dan mampu memenuhi keinginan dan kebutuhan masyarakat, untuk mewujudkan harapan masyarakat, sekolah dan guru harus mempunyai harapan yang tinggi terhadap siswa (Aziz, 2015).

\section{Faktor peningkatan mutu pendidikan}


Demi kemajuan kita bersama, maka selayaknya kita mengetahui dan memahami hal yang mampu meningkatakat mutu pendidikan, sebagaimana telah dijelas di atas akan pentingnya seluruth elemen masyarakat terkibat dalam hal ini, berikut merupakan faktor yang dapat meningkatkan mutu pendidikan.

Dari hasil penelitian Fadhil (2017) hal yang dapat meningkatkan mutu sekolah sebagai berikut:

1. Dukungan dari pemerintah.

2. Kepemimpinan kepala sekolah yang efektif.

3. Kinerja guru yang Profesinonal.

4. Kurikulum yang relevan.

Agar pembaca lebih memahami faktor-faktor diatas kami akan memaparkan lebih rinci pont-point tersebut:

1. Dukungan Pemerintah

Pada pembukaan Undang-undang Dasar Negara Republik Indonesia tahun 1945 (UUD 1945) bahwa pemerintah harus melindungi segenap bangsa Indonesia dan seluruh tumpah darah Indonesia dan untuk memajukan kesejahteraan umum, mencerdaskan kehidupan bangsa, dan ikut melaksanakan ketertiban dunia yang berdasarkan kemerdekaan, perdamian abadi dan keadilan sosial. Maka dari itu pemerintah diwajibkan untuk berusaha menyelenggarakan sistem pendidikan nasional bagi seluruh warga negara Indonesia.

Pemerintah berupaya dengan melakukan beragai program pendidikan sebagai implementasi penggunaan anggaran pendidikan di Indonesia sebanyak $20 \%$ dari APBN, terutama untuk daerah yang terpencil di pelosok negri Indonesia ini, pemerintah memegang peran penting dalam meningkatkan kualiatas pendidiakan, seperti akan ketersediaannya sarana dan prasarana contohnya gedung sekolah yang layak, juga ketersediaan bermacam fasilitas pendukung lainnya. Selain akan ketersidiaan sarana, prasarana dan fasilitas pendukung lainnya. 


\section{Kepemimpinan Kepala Sekolah yang Efektif.}

Kepemimpinana sekolah merpakan salah satu faktor yang sangat penting dalam satu organisasi karena semua hal yang terjadi dalam organisasi adalah dibentuk oleh pemimpin. Kepemimpinan adalah kemampuan yanag dimiliki seseorang dalam mempengaruhi orang lain untuk bekerja sama agar mencapai tujuan bersama. Dari hasil penelitian (Fitrah, 2017), kepala sekolah memilik peran dalam peningkatan mutu pendidikan sekolah sebagai berikut: Pertama, kepala sekolah memiliki kemampuan mentranformasikan ide dan imajinasi serta keinginan menjadi kenyatan. Kedua, sekolah itu berkualiatas tergantung pada pola pikir kepala sekolah, kerena pemimmpin tertinggi disekolah dan dialah yang bisa mengambil keputusan. Ketiga, dalam meningkatkan mutu pendidikan, kepala sekolah merupakan edukator, manajer, administrator, supervisor, leader, innovator dan motivator.

\section{Kinerja Guru yang Profesional}

Guru merupakan komponen penting dalam proses pembelajaran. Dengan keprofesinalitasnya, maka akan mampu memperbaiki proses pembelajaran sehingga dapat meningkatkan mutu pendidikan. Guru dapat meningkatkan mutu pembelajaran karena berfungsi dan berperan sebagai demonstrator, pengelola kelas, mediator, fasilitator dan evaluator (Sastrawan, 2016). Bersasarkan pendapat di atas, dapat diarikan secara singkat dengan hal yang sering kita dengarkan bahwa guru adalah yang digugu dan ditiru.

4. Kurikulum yang Relevan

Kurikulum merupakan rencana dalam bentuk dokumen yang dibuat untuk memastikan pencapaian tujuan pembelajaran. Kurikulum memiliki peran yang sangat penting dalam dunia pendidikan dan memiliki target pencapaian. Sehingga perlu kita memperhatikan bagaimana kurikulum yang 
sedang dijalankan apakah relevan atau tidak. Adanya perubahan kurkululum bertujuan untuk menyesuaiakan dengan perkembangan zaman, agar kurikulum yang dilakasanakan relevan.

Dalam melakasanakan manajemen kurikulum, ada hal yang menjadi pokok dasar sebagai berikut:

Dipaparkan oleh (Khoirudin, 2013).

1. Produktif

Hasil yang diperoleh dalam kurikulum merupakan aspek yang harus diperhitungkan.

2. Demokratis

Pelakasanaan manajemen kurikulum harus berdasasrkan demokrasi yang menempatkan pengelola, pelaksana dan subjek didik pada posisi yang seharusnya dalam melaksanakan tugas dengan penuh tanggungjawab untuk mencapai tujuan kurikulum.

3. Kooperatif

Untuk memperoleh hasil yang diahrapkan dalam kegiatan menajemen kurikulum perlu adanya kerjasama yang positif dari berbagai pihak yang terlibat.

4. Efektifitas

Rangkaian kegiatan manajemen kurikulum harus mempertimbangkan efektivitas dan efisiensi untuk mencapai tujuan kurikulum sehingga kegiatan manajemen kurikulum tersebut memberikan hasl yang berguna dengan biaya, tenaga, dan waktu yang relative singkat.

5. Mengarahkan visi, misi, dan tujuan yang ditetapkan dalam kurikulum

Proses menajemen kurikulum harus dapat memperkuat dan mengarahkan visi, misi, dan tujuan kurikulum.

\section{Penutup}


Pendidikan yang bermutu adalah pendidikan yang mampu melahirkan peserta didik yang intelektual, berpola pokir yang berkembang dan memiliki akhlak yang baik. Untuk meningkatkan pendidikan yang bermutu, tidak lah akan tercapai tanpa melalui faktor berikut ini; petama dukungan dari pemerintah; kedua kepemimpinan kepala sekolah yang efektif; ketika kinerja guru yang Profesinonal; keempat kurikulum yang relevan. Sebagai manusia yang berakal sehat memang seharusnya kita selalu berusaha untuk meraik yang terbaik. Jadikan hari ini sebagai pelajaran untuk masa depan.

\section{Referensi}

Fadhli, Muhammad. (2017). Manajemen Peningkatan Mutu Pendidikan. Jurnal Studi Manajemen Pendidikan, 1 (2), 219.

Aziz, Amrullah. (2015). Peningkatan Mutu Pendidikan. Jurnal Studi Islam, 10 (2) Desembar 5.

Suti, Marus. (2011). Strategi Pendidikan Mutu Era Otonomi Pendidikan. Jurnal Medtek, 3 (2) Oktober 2.

Hermanto, Saifulloh, Moh. \& Muhibin Zainul. (2011). Strategi Peningkatan Mutu Pendidikan di Sekolah. Jurnal Sosial Humaniora, 5 (2) November 206.

Fitrah, Muh. (2017). Peran Kepala Sekolah dalam Meningkatkan Mutu Pendidikan. Jural Penjaminan Mutu, 3 (1) 40.

Sastrawan, Ketut Bali. (2016). Profesionalisme Guru dalam Upaya Meningkatkan Mutu Pembelajaran. Jurnal Prnjaminan Mutu, 2 (2) 70-73.

Khoirudin, M. Arif. (2013). Manajemen Kurikulum dalam Meningkatkan Mutu Pendidikan. Jurnal Pemikiran Keislaman, 24 (1) 


\section{Data Penulis}

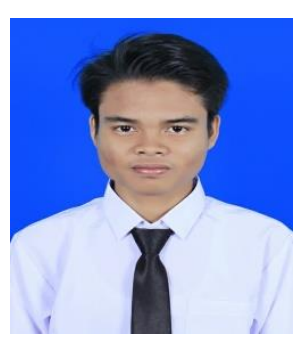

Atno Firnando, lahir di Taluk Kuantan, 26 Juli 2000. Setelah lulus di Madrasah Aliyah Babussalam Simandolak melanjutkan studi di Pendidikan Bahasa dan Sastra Indonesia FKIP Universitas Riau melalui jalur PBUD. Telah menjadi penulis pada buku: Sangkala "antologi cerpen", Bukan Daun Talas "antologi cerpen", Taman Jenaka "antologi fable", Tafakur "antologi puisi".

Kontak:

HP/WA : 082283130046

E-mail : atnofirnando12@gmail.com. 